\title{
Nutrient status, hematological and blood metabolite profile of mid-lactating dairy cows during wet and dry seasons raised under Indonesian tropical environmental conditions
}

\author{
Andriyani Astuti | Rochijan ${ }^{\mathrm{b}}$ | Budi Prasetyo Widyobroto ${ }^{\mathrm{b}}$ | Cuk Tri Noviandi
}

Department of Animal Nutrition and Feed Science, Faculty of Animal Science, Univeritas Gadjah Mada, Jl. Fauna No. 3, Bulaksumur, Yogyakarta 55281, Indonesia. Department of Animal Production, Faculty of Animal Science, Univeritas Gadjah Mada, Jl. Fauna No. 3, Bulaksumur, Yogyakarta 55281, Indonesia.

*Corresponding author: budi_widyobroto@ugm.ac.id

\begin{abstract}
This study was conducted to determine the nutrient status, changes in the hematological and selected blood metabolites profile of mid-lactating dairy cows during wet and dry seasons under Indonesia's tropical environment. Forty mid-lactating FH cows were selected from the Livestock Farm Complex (Dairy Community) in Yogyakarta, with an average body weight of $421.77 \pm 28.60 \mathrm{~kg}$ and $1^{\text {st }}$ to $3^{\text {rd }}$ lactation. They were housed in a semi-open housing system with concrete flooring covered with rubber mats and provided with feeders and drinkers. They were fed twice daily, and drinking water was given ad libitum. Measurements were made on the intakes of feed (and nutrients). The variables measured were nutrient intakes, blood hematology, and metabolites profile and measured over two seasons, namely wet and dry seasons. The results of the measurements made were compared using independent t-test analysis. The result indicated that intake of CP, RLYM, RNEUT, NEUT, RBC, HGB, MCV, MCHC, MPV, albumin, urea nitrogen, and total protein was differed significantly $(P<0.05)$ between wet and dry seasons, respectively. It was concluded that the nutrient status of mid-lactating dairy cows in the wet season was higher than during the dry season, especially the intake of CP. In the wet season, it has a positive effect on the basic hematological parameters.
\end{abstract}

Keywords: blood metabolite profile, dairy cows, hematology, mid-lactation, season

\section{Introduction}

The weather in Indonesia, which is situated in the tropics, is characterized by high temperature and humidity, ranging between 25.8 to $34.6{ }^{\circ} \mathrm{C}$ and 52.0 to $86.8 \%$, respectively (BPS 2010; Hernawan 2014; Rochijan et al 2016a; Widyobroto et al 2019) and temperature humidity index (THI) value in Indonesia is between 76.2 to 84.7 (Widyobroto et al 2019). This condition is likely to affect dairy cows' production, health, and nutrition raised in Indonesia.

Hematological and profile of blood metabolites have been used widely to monitor health status, nutritional status, and metabolism, identify dietary causes of low productivity, and evaluate animal stress and welfare levels (BruckaJastrzębska et al 2007). Effect of physiological status significantly manifested on the blood metabolic profile and hormones (leptin, insulin, and thyroid hormones) (Antunovic et al 2011). Physiological changes in constituents of blood cells and blood metabolites occur dynamically during growth, pregnancy, and lactation.

The blood metabolites profiles are also considered important in evaluating the health (Khalili et al 2020) and nutritional status of cows. The present study examined the nutrient status, hematological, and some of the blood metabolites profiles of mid-lactating dairy cows under wet and dry seasons under Indonesia's tropical environment.

\section{Materials and Methods}

\subsection{Ethical approval}

The animal procedure herein used was approved by the Ethical Clearance Committee, and it was performed following the Guidelines of Animal Use of the Faculty of Veterinary Medicine, Universitas Gadjah Mada, Indonesia.

\subsection{Animal, diets, and feed analysis}

Forty Friesian Holstein cows in their mid-lactation were selected from the Livestock Farm Complex (Dairy Community) in Yogyakarta, Indonesia during the wet and dry seasons. The cows (average body weight $421.7 \pm 28.6 \mathrm{~kg}$ ) were on $1^{\text {st }}$ to $3^{\text {rd }}$ lactation. The experimental animals were reared in a semi-open housing system with a concrete floor, covered with rubber mats, and supplied with feeders and automatic drinkers. The roofs were made of asbestos roofing material, and the house was constructed in an east-west direction. Daily temperature and humidity are generally high during the 
study, i.e., $31.3{ }^{\circ} \mathrm{C}$ and $64.1 \%$; and temperature humidity index (THI) value is 82.1. The cows were fed twice daily, at 07.00 and $15.00 \mathrm{~h}$, with forages and concentrate given separately, and drinking water was given ad libitum. The proportion and chemical composition of forage (Pennisetum purpureum and Panicum maximum) and commercial concentrate was presented in Table 1. Collecting of samples was conducted daily during the study. The proximate composition of feed sample (forage and commercial concentrate) and feed refusals were analyzed by the AOAC method (2005) to measure their moisture content, dry matter, organic matter, crude protein, crude fiber, extract ether, and total digestible nutrients.

Table 1 Proportion (\%) and chemical composition forage and concentrate.

\begin{tabular}{lccc}
\hline Parameters & \multicolumn{2}{c}{ Forages (\%) } & Concentrate (\%) \\
\cline { 2 - 3 } & \multicolumn{1}{c}{ Pennisetum purpureum } & Panicum maximum & 43.00 \\
Season & 57.00 & - & 43.60 \\
Det season & - & 56.40 & 85.57 \\
\hline Nutrient composition (\% DM) & & & 92.09 \\
Dry matter & 26.88 & 32.87 & 21.84 \\
Organic matter & 87.19 & 90.22 & 27.66 \\
Crude protein & 7.01 & 5.22 & 0.11 \\
Crude fiber & 34.87 & 33.64 & 60.87 \\
Extract ether & 1.96 & 0.92 & 44.39 \\
Total digestible nutrients & 50.98 & 55.14 & 12.62 \\
Neutral detergent fiber (\%) & 66.70 & 70.11 & 40.29 \\
Acid detergent fiber (\%) & 37.59 & & \\
\hline
\end{tabular}

\subsection{Blood sampling and analysis}

During respective wet and dry seasons, blood samples from each animal (once in every two weeks) were collected aseptically from the caudal artery ( 3 to $4 \mathrm{~h}$ after the morning feeding) into $3 \mathrm{~mL}$ vacutainer $\mathrm{K} 3$ Ethylene Diamine Tetraacetic Acid (EDTA) tubes. The tubes were rolled several times gently to ensure enough anticoagulant mixing with Delany et al (2010) methods, modified by Rochijan et al (2016a) to sample preparation. Immediately after collection, the samples were transported to the laboratory over ice for further processing. The samples were analyzed for hematological parameters, namely white blood cell (WBC), the ratio of lymphocytes (RLYM), the ratio of eosinophil granulocytes, basophil granulocytes and monocytes (REBM), the ratio of neutrophil granulocytes (RNEUT), lymphocytes (LYM), eosinophil granulocytes, basophil granulocytes and monocytes (EBM), neutrophil granulocytes (NEUT), red blood cell (RBC), hemoglobin concentration (HGB), hematocrit value (HCT), mean corpuscular volume (MCV), mean corpuscular hemoglobin $(\mathrm{MCH})$, mean corpuscular hemoglobin concentration (MCHC), platelets (PLT) and mean platelet volume (MPV) using automated hematology analyzer (Make Mindrey; model BC 2800). Then the blood samples were centrifuged for $15 \mathrm{~min}$ at $3000 \mathrm{rpm}$, and the plasma was taken using a micropipette and then transferred into $1 \mathrm{~mL}$ Eppendorf tube. The blood plasma samples were then stored at a temperature of $-20{ }^{\circ} \mathrm{C}$ freezer until blood urea nitrogen analysis. After being collected, the plasma concentration of glucose, albumin, urea nitrogen, total protein, and total cholesterol were determined using an auto-analyzer.

\subsection{Statistical analysis}

The data obtained were statistically analyzed by independent t-test analysis using Statistical Program for Social Science or SPSS version 24.0.

\section{Results and Discussion}

\subsection{Microenvironment condition during wet and dry seasons}

Many environmental factors such as the climate can interfere with the productivity of dairy cows, feed consumption, weight gain, body health, hematological and blood metabolite profile. Dairy cows are susceptible to a hot environment (heat stress) which can cause changes in the endocrine system in the blood. Table 2 shows the result of the study in the microenvironment condition during the wet and dry seasons (temperature, humidity, wind/velocity, and solar radiation).

Table 2 shows that the average temperature in the wet season was $27.1 \pm 3.5^{\circ} \mathrm{C}$ and $26.7 \pm 3.8^{\circ} \mathrm{C}$ in the dry season. According to Yousef (1985), the temperatures are above the Thermo Neutral Zone (TNZ) for dairy cattle ranging from 16 to $25{ }^{\circ} \mathrm{C}$, so that the cows begin to experience stress. The average daily humidity in the wet season was $82.1 \pm 9.0 \%$ and $81.0 \pm 8.0 \%$ in the dry season. Humidity is relatively high because of high rainfall. The impact of low or high humidity 
causes the cow will make adjustments by increasing or decreasing the frequency of respiration, feed intake, and level productivity. There is a significant difference in solar radiation. According to De Rensis and Scaramuzzi (2003), environmental factors that affect reproductive efficiency, body health, nutrient consumption, and production include temperature, solar radiation, humidity, wind or velocity, and rainfall which contribute significantly to heat stress levels in dairy cows.

\subsection{Nutrient status of cows during wet and dry seasons}

The average intake of dairy cows during the wet and dry seasons is presented in Table 3. The intakes of DM, OM, $\mathrm{CF}$, and TDN did not show significant differences between wet and dry seasons. However, the intakes of crude protein were significantly higher $(P<0.05)$ in cows during the dry season compared to the wet season. The consumption of OM is positively correlated with dry matter intake (DMI). The DMI has special importance to meet the nutrient requirement of fresh cows (early lactation) to maintain their health and production (Rochijan et al 2016b). Le Floc'h et al (2004) and Sejrsen et al (2006) reported that low DMI and deficiency in nutrient supply, especially protein and amino acids, have led to immunosuppression and incidence of metabolic disorders in cows. Thus, diets with higher CP and undegraded protein are effective in maintaining production and body condition score (BCS) (NRC 2001).

In this study, dietary concentrate:forage ratio of total feed consumed in the wet season (43.0:57.0) and dry season (43.6:56.4) (Table 3) were not significantly different. Results of the study are comparable with those obtained by Cantalapiedra-Hijar et al (2009) and Ramos et al (2009), who found no effect of dietary concentrate: forage ratios (30:70 and 70:30) on OM intake in both goats and sheep fed above maintenance. The differences in CF of the diets were mainly due to the variance in CF concentrations. However, Allen (2000) noted that no effect of CF ranging from 25 to $40 \%$ was found on DM intake in dairy cows, although feed intake generally decreases with increasing CF. Furthermore, the forages intake was low, negatively affecting the digestive process because the concentrates had a high $\mathrm{CP}$ and structural carbohydrate. Farmers should utilize this situation as a reference, especially during the dry season when forages are expensive and hard to find. Energy in feed could affect the efficiency of the ration used, especially in ruminants. Excess energy in the ration causes a reduction in feed efficiency, and it tends to build in the body fat. One of the disadvantages was that there were excesses in the supply of amino acids, which will be deaminated and excreted, with a consequent reduction in the energy value of the diet.

Table 2 Microenvironment condition during the wet and dry seasons.

\begin{tabular}{lcccccc}
\hline \multirow{2}{*}{ Parameters } & \multicolumn{3}{c}{ Wet Season } & \multicolumn{3}{c}{ Dry Season } \\
\cline { 2 - 7 } & Min. & Max. & Average & Min. & Max. & Average \\
\hline Temperature $\left({ }^{\circ} \mathrm{C}\right)$ & 21.9 & 33 & $27.1 \pm 3.5^{\mathrm{a}}$ & 20.3 & 32.5 & $26.7 \pm 3.8^{\mathrm{a}}$ \\
Humidity (\%) & 64 & 95 & $82.1 \pm 9.0^{\mathrm{a}}$ & 62 & 93 & $81.0 \pm 8.0^{\mathrm{a}}$ \\
Wind / Velocity (m/s) & 2 & 14 & $5.2 \pm 3.8^{\mathrm{a}}$ & 2 & 12 & $4.5 \pm 3.3^{\mathrm{a}}$ \\
Solar radiation (\%) & 26 & 77 & $51.8 \pm 12.9^{\mathrm{a}}$ & 50 & 78 & $64.4 \pm 9.2^{\mathrm{b}}$ \\
\hline
\end{tabular}

${ }^{\text {ab }}$ Different superscripts within rows indicate significant differences $(P<0.05)$.

Table 3 Nutrient intake of lactating dairy cows during the wet and dry seasons.

\begin{tabular}{llc}
\hline & \multicolumn{2}{c}{ Groups (kg DM/head/day) } \\
\cline { 2 - 3 } Nutrient Intake & Wet Season & Dry Season \\
\cline { 2 - 3 } & (Mean \pm SD) & $19.06 \pm 2.69^{\mathrm{a}}$ \\
\hline Dry matter & $18.72 \pm 3.73^{\mathrm{a}}$ & $17.33 \pm 2.44^{\mathrm{a}}$ \\
Organic matter & $16.72 \pm 3.28^{\mathrm{a}}$ & $2.22 \pm 0.43^{\mathrm{b}}$ \\
Crude protein & $2.52 \pm 0.37^{\mathrm{a}}$ & $5.97 \pm 0.85^{\mathrm{a}}$ \\
Crude fiber & $5.94 \pm 1.26^{\mathrm{a}}$ & $10.93 \pm 1.54^{\mathrm{a}}$
\end{tabular}

${ }^{\text {ab }}$ Different superscripts within rows indicate significant differences $(P<0.05)$.

\subsection{Blood hematological profile of cows during wet and dry seasons}

Blood hematological profile in ruminants, especially for dairy cows, depends on many factors linked to the animal's physiological status and management system, including housing hygiene, health, and nutrition. For the dairy cows to perform normally and productively, appropriate management conditions are required. According to BruckaJastrzębska et al (2007), hematological blood tests primarily aim to monitor health status, detect possible diseases, and evaluate animal stress and welfare levels. Results of the 
hematological blood profiles in cows during the wet and dry seasons are shown in Table 4. It showed that in all groups, the values of the significant blood morphological indicators fell within the range of reference values for healthy dairy cows. WBC are the basic cells of the immune system in humans and animals, which determine normal body function. In both wet and dry seasons, the mean white blood cell count in all cows was fell within the reference range (Winnicka 2008; QuirozRocha et al 2009; Patel et al 2017).

In this study, the cows in the wet season have a higher concentration of white and red cell counts, hemoglobin concentration, hematocrit value, and platelets compared to during the dry season. In this study, statistically significant differences $(P<0.05)$ were observed in the concentration on red cell counts, the ratio of lymphocytes, the ratio of neutrophil granulocytes, neutrophil granulocytes, hemoglobin concentration, mean corpuscular volume, mean corpuscular hemoglobin concentration, and mean platelet volume were found in cows between the seasons. The present study showed that most hematological parameters were higher during the wet season than during the dry season in cows. White cell count was observed to increase significantly $(P<0.05)$ in cows during the wet season compared to the dry season. The white cells of animals observed in the wet season were significant higher than in the dry season, indicating that the cows' immune system was increased. However, there was no evidence of pathology in the observation. The result of leukocyte count in cattle may also increase due to stress, including blood collection (Brucka-Jastrzębska et al 2007).

Table 4 Concentrations of hematological blood profile in cows during the wet and dry seasons.

\begin{tabular}{|c|c|c|c|}
\hline \multirow{2}{*}{ Parameters } & \multicolumn{2}{|c|}{ Groups } & \multirow{2}{*}{ Normal Values } \\
\hline & Wet Season & Dry Season & \\
\hline 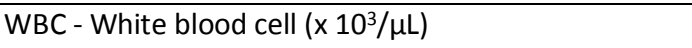 & $15.35^{\mathrm{a}}$ & $14.78^{a}$ & $5-13.3(1)$ \\
\hline RLYM - Ratio of lymphocytes (\%) & $24.08^{a}$ & $45.50^{b}$ & - \\
\hline $\begin{array}{l}\text { REBM - Ratio of eosinophil granulocytes, basophil } \\
\text { granulocytes and monocytes (\%) }\end{array}$ & $5.55^{\mathrm{a}}$ & $2.16^{\mathrm{a}}$ & - \\
\hline RNEUT - ratio of neutrophil granulocytes (\%) & $70.37^{a}$ & $52,35^{b}$ & - \\
\hline LYM - Lymphocytes (x 103/ $\mu \mathrm{L})$ & $3.28^{\mathrm{a}}$ & $9.45^{\mathrm{a}}$ & $1.8-8.1(1)$ \\
\hline $\begin{array}{l}\text { EBM - Eosinophil granulocytes, basophil granulocytes } \\
\left.\text { and monocytes ( } \times 10^{3} / \mu \mathrm{L}\right)\end{array}$ & $0.82^{\mathrm{a}}$ & $0.19^{a}$ & $0.1-1.1(1)$ \\
\hline NEUT - Neutrophil granulocytes $\left(\times 10^{3} / \mu \mathrm{L}\right)$ & $10.31^{\mathrm{a}}$ & $5.15^{b}$ & $1.7-6(1)$ \\
\hline RBC - Red blood cell (x 106/ $\mu \mathrm{L})$ & $7.11^{\mathrm{a}}$ & $5.74^{b}$ & $5-10(2)$ \\
\hline HGB - Hemoglobin concentration (g/dL) & $12.20^{\mathrm{a}}$ & $9.63^{b}$ & $8-15(2)$ \\
\hline HCT - Hematocrit value (\%) & $33.05^{\mathrm{a}}$ & $27.89^{a}$ & $24-46(2)$ \\
\hline MCV - Mean corpuscular volume (fL) & $46.50^{\mathrm{a}}$ & $48.75^{b}$ & $40-60(2)$ \\
\hline $\mathrm{MCH}$ - Mean corpuscular hemoglobin (pg) & $17.74^{a}$ & $16.84^{a}$ & $11-17(2)$ \\
\hline $\begin{array}{l}\text { MCHC - Mean corpuscular hemoglobin } \\
\text { concentration }(\mathrm{g} / \mathrm{dL})\end{array}$ & $38.21^{\mathrm{a}}$ & $34.57^{b}$ & $30-36(2)$ \\
\hline PLT - Platelets (x 104/ $\mu \mathrm{L})$ & $66.10^{a}$ & $38.71^{\mathrm{a}}$ & - \\
\hline MPV - Mean platelet volume (fL) & $6.89^{a}$ & $7.33^{b}$ & - \\
\hline
\end{tabular}

\footnotetext{
a,b Different superscripts within rows indicate significant differences $(P<0.05)$.

(1) Hoff and Duffield (2003).

(2) Morris (2009)
}

There are studies on the effect of management systems blood parameters in the scientific literature, but their results are inconclusive. The previous study suggests that red blood cell parameters and hemoglobin concentration do not show significant seasonal differences (Deptuła and Dorynek, 1993). Furthermore, Kumar and Pachaura (2000) discovered that during the dry season, hemoglobin concentration, mean corpuscular hemoglobin, mean corpuscular hemoglobin concentration, and mean cell volume all increased in crossbred dairy cattle, but the hematocrit value decreased.

The mean corpuscular volume and the mean corpuscular hemoglobin concentration decreased in response to high temperature, but there were no changes in white and red blood cell counts, hematocrit value, and hemoglobin concentration (Casella et al 2013; Mazzullo et al 2014). Another study, Patel et al (2017) reported a reduction in hemoglobin, hematocrit value, mean corpuscular volume, and mean corpuscular hemoglobin concentration during the 
dry season, but no change was observed in red and white blood cell count and MCHC. The hemoglobin level, erythrocyte count, and hematocrit value are all factors that influence red blood cell parameters. According to Aengwanich et al (2009), MCV can be employed in the hematological analysis of a response to thermal and humidity stress in dairy cattle. The same study revealed that stress caused by high temperatures and humidity conditions had been shown to impact hemoglobin synthesis, most likely lowering the available metabolites affected the thyroid and body metabolic failure.

\subsection{Blood metabolites profile of cows during wet and dry seasons}

Based on Scamell's study (2006), biochemical blood tests are commonly used to assess a human's, TGE functions of the organ (e.g., kidneys and liver), and metabolic processes. It's critical to select the appropriate biochemical parameters that determine how various the functions of organs or systems. In cows, the concentration of glucose, free fatty acids, and beta-hydroxybutyric acid are considered an indicator of energy metabolism. In contrast, the indicators of protein metabolism are urea, total protein, and albumins. In this study, most of the biochemical parameters (Table 5) had values that fall within the range of reference values proposed by Winnicka (2008), Quiroz-Rocha et al (2009), and Patel et al (2017). In this study, no statistically significant differences in blood glucose and total cholesterol concentration were found in the cows, and this finding is supported by the findings of Brzóska (2005). However, the concentration of blood urea nitrogen, albumin, and total protein showed statistically significant $(P<0.05)$.

Urea nitrogen concentration in blood and milk is one of the indicators of the nutritional status of dairy cows. It was shown that the urea nitrogen and total protein concentration in the blood of experimental cows, which was relatively high but were within normal limits. The urea nitrogen of blood indicated that feed protein was efficiently utilized by rumen microflora. The high nitrogen level in forage may affect hepatic nitrogen metabolism, manifested by higher serum activity. The concentration of these enzymes can also be influenced by ambient temperature. According to Brzóska (2006) cows ingest relatively high amounts of dry matter with a high protein content during both the summer or dry season, which is rapidly metabolized to ammonia in the rumen. Cerutti et al (2018) found aminotransferase activity to increase during the dry season in response to high temperature, and lower cholesterol concentrations in the plasma of cows during the dry season compared with the wet season.

Table 5 Concentrations of blood metabolites profile in cows during the wet and dry seasons.

\begin{tabular}{lcc}
\hline & \multicolumn{2}{c}{ Groups } \\
\cline { 2 - 3 } Parameters & $\begin{array}{c}\text { Wet Season } \\
\text { (Mean } \pm S D)\end{array}$ & $\begin{array}{c}\text { Dry Season } \\
\text { (Mean } \pm S D)\end{array}$ \\
\hline Glucose $(\mathrm{mg} / \mathrm{dL})$ & $36.20 \pm 5.85^{\mathrm{a}}$ & $37.24 \pm 8.04^{\mathrm{a}}$ \\
Albumin $(\mathrm{g} / \mathrm{dL})$ & $4.04 \pm 0.48^{\mathrm{a}}$ & $3.63 \pm 0.26^{\mathrm{b}}$ \\
Urea nitrogen $(\mathrm{mg} / \mathrm{dL})$ & $36.76 \pm 5.58^{\mathrm{a}}$ & $23.12 \pm 7.28^{\mathrm{b}}$ \\
Total protein $(\mathrm{g} / \mathrm{dL})$ & $6.06 \pm 1.56^{\mathrm{a}}$ & $8.05 \pm 0.60^{\mathrm{b}}$ \\
Total cholesterol $(\mathrm{mg} / \mathrm{dL})$ & $106.00 \pm 21.30^{\mathrm{a}}$ & $119.60 \pm 26.15^{\mathrm{a}}$ \\
\hline $\mathrm{a}, \mathrm{b}$ Different superscripts within rows indicate significant differences $(P<0.05)$.
\end{tabular}

\section{Conclusions}

It was concluded that the nutrient intake of midlactating dairy cows during the wet season was higher than during the dry season, especially on the intake of $\mathrm{CP}$, probably due to the higher availability of concentrates and less forages supplied to the cows. The wet season positively affects the basic hematological parameters, and hence, affects dairy cows' welfare.

\section{Conflict of Interest}

The authors declare that there is no conflict of interest with this work.

\section{Funding}

This study was supported by the PTUPT Grant from the Directorate of Resources Affairs, the Directorate General of Higher Education, Research, and Technology, the Ministry of
Education, Culture, Research, and Technology, Republic of Indonesia (KEMDIKBUDRISTEK-RI) and Universitas Gadjah Mada.

\section{References}

Aengwanich W, Chantiratikul A, Pamok S (2009) Effect of seasonal variations on hematological values and health monitor of crossbred beef cattle at slaughterhouse in northeastern part of Thailand. American-Eurasian Journal of Agricultural \& Environmental Sciences 5:644-648.

Allen MS (2000) Effects of diet on short-term regulation of feed intake by lactating dairy cattle. Journal of Dairy Science 83:1598-1624.

Antunovic Z, Novoselec J, Sauerwein H, Speranda M, Vegara M, Pavic V (2011) Blood metabolic profile and some of hormones concentration in ewes during different physiological status. Bulgarian Journal of Agricultural Science 17:687-695.

AOAC (2005) Official Method of Association of Official Analytical Chemist. $18^{\text {th }}$ Edition. Association of Official Analytical Chemist. Benjamin Franklin Station. Washington, DC., USA.

BPS (2010). Statistik Indonesia 2010 [Statistics Indonesia 2010]. Badan Pusat Statistik (BPS), Jakarta, Indonesia, (In Indonesian). 
Brucka-Jastrzębska E, Kawczuga D, Brzezińska M, Orowicz W, Lidwinkaźmierkiewicz M (2007) Zależność parametrów hematologicznych bydła rasy simental od stanu fizjologicznego (Dependence of hematological parameters in Simmental breed cattle on physiological conditions). In Polish, summary in English. Medycyna Weterynaryjna 63:1583-1586.

Brzóska $F$ (2005) Effect of soybean meal protected with Ca salts of fatty acids on cows' yield, protein and fat components in milk and blood. Annals of Animal Science 5:111-123.

Brzóska F (2006) Effect of rapeseed meal protected with calcium salts of fatty acids from linseed oil on cows' yield and milk and blood parameters. Annals of Animal Science 6:87-99.

Cantalapiedra-Hijar G, Yanez-Ruiz DR, Martin-Garcia Al, Molina-Alcaide E (2009) Effects of forage: concentrate ratio and forage type on apparent digestibility, ruminal fermentation and microbial growth in goats. Journal of Animal Science 87:622-631.

Casella S, Scianò S, Zumbo A, Monteverde V, Fazio F, Piccione G (2013) Effect of seasonal variations in Mediterranean area on haematological profile in dairy cow. Comparative Clinical Pathologhy 22:691-695.

Cerutti RD, Scaglione MC, Arfuso F, Rizzo M, Piccione G (2018). Seasonal variations of some hematochemical parameters in Holstein bovine under the same livestock conditions. Veterinarski Arhiv 88:309-321.

De Rensis F, Scaramuzzi RJ (2003) Heat stress and seasonal effects on reproduction in the dairy cow - a review. Theriogenology 60:1139-1151.

Delany KK, Macmillan KL, Grainger C, Thomson PC, Blache D, Nicholas KR Auldist MJ (2010) Blood plasma concentrations of metabolic hormones and glucose during extended lactation in grazing cows or cows fed a total mixed ration. Journal of Dairy Science 93:5913-5920.

Deptuła W, Dorynek Z (1993) Kształtowanie się wskaźników hematologicznych I biochemicznych u krów mlecznych w cyklu rocznym (Modification of hematological and biochemical indexes in dairy cows in the annual cycle). In Polish. Roczniki Akademii Rolniczej w Poznaniu 246:15-21.

Hernawan AE (2014) Effect of banana peel application in ration on hematological level, nitrogen retention and body weight gain of heat exposed broiler chicken. Scientific Papers. Series D. Animal Science 42:101107.

Hoff B, Duffield T (2003) Nutritional and metabolic profile testing of dairy cows. AHL LabNote 4:1-3.

Khalili M, Chamani M, Amanlou H, Nikkhah A, Sadeghi AA, Dehkordi FK, Rafiei $M$, Shirani $V$ (2020) The effect of feeding inorganic and organic selenium sources on the hematological blood parameters, reproduction and health of dairy cows in the transition period. Acta Scientiarum Animal Science 42:1-10.

Kumar B, Pachaura SP (2000) Hematological profile of crossbreed dairy cattle to monitor herd health status at medium elevation in central Himalayas. Research in Veterinary Science 69:141-145.

Le Floc'h N, Melchior D, Obled C (2004) Modifications of protein and amino acid metabolism during inflammation and immune system activation. Livestock Production Science 87:37-45.

Mazzullo G, Rifici C, Cammarata F, Caccamo G, Rizzo M, Piccione G (2014) Effect of different environmental conditions on some haematological parameters in cow. Annals of Animal Science 14:947-954.

Morris DD (2009) Alterations in the Leukogram. In: Smith BP (2009) Large Animal Internal Medicine. $4^{\text {th }}$ Edition. Mosby, St. Louis. 405-410.

NRC (2001) Nutrient Requirements of Dairy Cattle. $7^{\text {th }}$ Revised Edition, National Academy Press, Washington, DC., USA.

Patel B, Kumar N, Jain V, Kumar F, Ajithakumar HM, Naik MA, Lathwal SS (2017) Haematological status of karan fries cows during transition period in hot humid condition. International Journal of Science, Environment and Technology 6:793-797.

Quiroz-Rocha GF, LeBlanc SJ, Duffield TF, Wood D, Leslie KE, Jacobs RM (2009) Reference limits for biochemical and hematological analytes of dairy cows one week before and one week after parturition. The Canadian Veterinary Journal 50:383-388.

Ramos S, Tejido ML, Martinez ME, Ranilla MJ, Carro MD (2009) Microbial protein synthesis, ruminal digestion, microbial populations and nitrogen balance in sheep fed diets varying in forage-to-concentrate ratio and type of forage. Journal of Animal Science 87:2924-2934.

Rochijan, Widyobroto BP, Ismaya (2016a) Effect of high rumen undegraded protein (HRUP) supplementation on estrous response and progesterone hormone profile in dairy cows raised under Indonesia tropical environmental conditions. Asian Journal of Animal Science 10:175-181.

Rochijan, Widyobroto BP, Ismaya (2016b) Impact of high rumen undegraded protein (HRUP) supplementation to blood urea nitrogen and reproduction performance in early lactation dairy cows. International Journal of Dairy Science 11:28-34.

Scamell JM (2006) Healthy land for healthy cattle. Cattle Practice 14:143152.

Sejrsen K, Hvelplundand T, Nielson MO (2006) Ruminant Physiology: Digestion, Metabolism and Impact of Nutrition on Gene Expression, Immunology and Stress. Wageningen Academic Publishers, Wageningen, the Netherlands. ISBN-13: 9789076998640.

Widyobroto BP, Rochijan, Noviandi CT, Astuti A (2019) Microenvironment identification and the feed availability for dairy cows during dry and wet seasons in the main dairy areas of Yogyakarta - Indonesia. Journal of Animal Behaviour and Biometeorology 7:86-91.

Winnicka A (2008) Wartości referencyjne podstawowych badań laboratoryjnych w weterynarii (Reference values in basic laboratory analyses in veterinary medicine). In Polish. Wydawnictwo Szkoła Główna Gospodarstwa Wiejskiego, Warszawa 99:17-39.

Yousef MK (1985) Stress Physiology in Livestock. Vol. 1. Boca Raton: CRC Press. 